\title{
The Origins and Dynamics of Export Superstars
}

\section{Caroline Freund and Martha Denisse Pierola}

\begin{abstract}
Export superstars are important for export growth and diversification and are typically born large. Firm-level data on manufacturing trade from 32 developing countries show that the top five exporters account for on average nearly one-third of exports, 47 percent of export growth, and a third of the growth due to export diversification over a five-year period. Within countries and industries, export growth is positively correlated with the share of exports in the top five firms. Most of the top five exporters were already large five (or eight) years ago or are new firms; it is rare for these export superstars to emerge from the bottom half of the distribution of firm sizes. For countries where detailed data exist, superstars are producers, not traders, and are primarily foreign owned.
\end{abstract}

JEL classification: D22, L11, L25, F14

Keywords: firm size distribution, export growth, export diversification, granularity, foreign ownership

\section{Introduction}

The dominance of large firms in aggregate exports has been widely documented in the existing trade literature. Bernard, Jensen, and Schott (2009) show that the top 1 percent of exporters in the United States are responsible for 80 percent of the total export value. Similarly, Eaton, Kortum, and Kramarz (2011) display a highly skewed distribution of the size of exporters for French firms, and Mayer and Ottaviano (2008) document a similar pattern for seven European countries. While several of these studies

Martha Denisse Pierola (corresponding author) is a Senior Economist at the Inter-American Development Bank; her email address is mpierola@iadb.org. Caroline Freund is Director of Trade, Regional Integration and Investment Climate at the World Bank; her email address is cfreund@worldbank.org. The authors are grateful to Mirvat Sewadeh and Vanessa Uchiyama for their assistance in conducting interviews with export superstars in Jordan, Peru, and Tanzania and to Sarah Oliver for doing research on the characteristics of the top five exporters across a larger group of countries. The authors are also grateful to Erhan Artuc, Richard Baldwin, Juan Blyde, Chad Bown, Deniz Civril, Jonathan Eaton, Ana Fernandes, James Harrigan, Gary Hufbauer, Hiau Looi Kee, Sam Kortum, Aart Kraay, Ricardo Lopez, Aaditya Mattoo, Ferdinando Monte, Emanuel Ornelas, Justin Pierce and Andres Rodriguez-Clare for useful comments on earlier versions of this paper and to seminar participants at the London School of Economics, Yale University, the Federal Reserve Bank of New York, the Graduate Institute of International and Development Studies, the Peterson Institute for International Economics, the Empirical Investigations in International Trade Conference, the Eastern Economic Association Annual Meetings, the workshop on Trade Policy for Growth organized by the World Bank, the International Growth Center and the Mid-Atlantic Trade Workshop. The findings expressed in this paper are those of the authors and do not necessarily represent the views of the institutions they are affiliated with. This work was supported financially by the governments of Norway, Sweden, and the United Kingdom through the Multi-Donor Trust Fund for Trade and Development. The authors also acknowledge the generous financial support from the World Bank research support budget and the Knowledge for Change Program (KCP), a trust-funded partnership in support of research and data collection on poverty reduction and sustainable development housed in the office of the Chief Economist of the World Bank (www.worldbank.org/kcp). 
focus on the skewness in the distribution of the size of firms and show that a small fraction of firms generates a large share of trade, the recent literature goes further and analyzes the extent to which the largest individual exporters matter for trade flows. In earlier work, we showed how the top five firms transform sectoral patterns and alter comparative advantage (Freund and Pierola 2015). These export superstars are firms-like Samsung in Korea and Vietnam, Foxconn in China, and Intel in Costa Ricathat shape a country's exports. ${ }^{1}$ That work does not, however, explore the importance of superstar firms for export growth, export diversification, or examine where superstars originate.

In this paper we examine the extent to which superstars contribute to export growth and diversification, and uncover their history. These additional characteristics are important because an international policy goal of many governments is export expansion and diversification. Given that earlier work has shown that export superstars are important in trade, it may be logical to assume they are equally important in short-run trade growth; however, it does not follow that they are necessary for export diversification. Although evidence on multiproduct firms shows that firms that export to many destinations account for a large share of exports (Bernard, Redding, and Schott 2010), the extent of their contribution to growth of exports and diversification has not been explored. Large firms could be the primary source of intensive margin growth, while young smaller export startups could be responsible for the growth of new products. Alternatively, it may be that large firms find it easier to pay the fixed costs of exporting a new product to a new market and account for most of the diversification. In addition, the origin of new superstars, which contribute enormously to export growth, would offer information to policy makers about how common it is for new superstars to emerge and where they are likely to come from.

Using a firm-level panel for 32 countries, we show the importance of the top five firms in export growth and diversification and uncover facts about their beginnings. Over the most recent period with data available for five consecutive years in each country, the export superstar firms-defined as the top five firms in year 5 in the sample for each country-account for 47 percent of export growth. Their role in export diversification is also important. When the extensive margin is defined at the country levelproducts and/or markets new to the country-the top five firms account for a third of the total extensivemargin export growth during that period. When the extensive margin is defined at the firm level-exports of all new firms and products and/or markets new to a firm-superstars account for 55 percent of the total export growth driven by that margin.

A notable feature of the data is that export superstars are even more important for export growth than for export volumes, which explains why exporter concentration tends to rise over the period. Increased concentration does not merely reflect a shift to more capital-intensive sectors as it occurs within industries as well. In particular, within countries and industries, or even within country-industries, exports are positively and significantly correlated with the share of exports accounted for by the top five firms. The positive correlation between exporter concentration and export growth appears to contradict work by Arkolakis (2016), who finds that small firms grow faster. But, there is a major difference between growth and contribution to growth because the distribution of the size of exporters is highly skewed and lumpy, with some superstars and some tiny exporters. While the tiny exporters do grow faster, their contribution to aggregate export growth is minimal because they account for a small fraction of exports.

1 Results from this literature are consistent with a growing body of macroeconomic work showing that large firms explain a sizable share of aggregate economic behavior. Gabaix (2011) finds that idiosyncratic shocks to the largest firms in the United States explain about one-third of GDP fluctuations. Di Giovanni, Levchenko, and Mejean (2014) find even more pronounced effects in France and show that input and output linkages between firms transmit shocks. International trade magnifies these effects, especially in small countries, because the most productive firms grow larger when their market is the world (Di Giovanni and Levchenko 2012). Gaubert and Itshoki (2016) find that granularity explains 30 percent of trade flows and sectoral welfare gains from liberalization are shaped by the granularity in a sector. 
The origins of export superstars are also explored. New firms growing quickly into export superstars is not unusual, on average 29 percent of the superstars were nonexistent eight years ago. Superstars begin exporting at a relatively large scale and grow quickly into the top 1 percent. In particular, 55 percent of the new exporters that became top five firms during the last consecutive five-year period entered the export sector within the top 1 percent of exporters and on average grew into superstars within two years. In addition, 84 percent of the incumbent superstars were already part of the top 1 percent nearly one decade ago, so cases of exporters transitioning slowly from the bottom to the top of the size distribution are rare. These results reveal that superstars tend to start as large exporters and grow fast, implying that the majority are already highly productive upon entering the export sector, and that the learning period before becoming a superstar is short.

The data do not allow systematic examination of superstars before they began exporting to learn about their experience in domestic markets. However, for nine countries where the superstars can be identified by name, it was possible to research and learn more about some characteristics surrounding their presence and origins. First, the results show that the majority of superstars are foreign owned. The larger foreign share in ownership of superstars highlights the role of multinational companies in exports. Second, only a tiny fraction of the superstars are traders, firms that primarily export production that they did not produce. Third, the top exporting firms began exporting shortly after they had been established. ${ }^{2}$

These findings have several implications. From an empirical perspective, the presence of these dominant firms implies that the results from studies that evaluate how the average firm responds to trade liberalization may not properly reflect aggregate effects, if large or fast-growing firms behave differently. From a policy perspective, governments interested in growing exports should consider the environment for creating export superstars. This does not imply that large firms should be subsidized, but that governments should ensure that incentives are in place for the most productive firms to grow large and have access to foreign markets. While superstars are almost always born relatively large, they still need to expand significantly to become a top five firm, given the extraordinary skewness of the distribution of the sizes of exporters. For example, a firm born at the cutoff for the top 1 percent of exporters would need to grow more than seven-fold, on average, to become a top five firm. The evidence on superstar origins highlights that foreign investment promotion may be the most effective strategy for creating export superstars quickly.

This paper is organized as follows. Section 2 introduces the data. Section 3 records the contribution of large exporters to export growth and diversification. Section 4 delves into the origin of superstars, and section 5 concludes.

\section{Data on Firm Exports}

The complete dataset used for this paper contains exporter-level information on manufacturing exports from a total of 32 developing countries in different regions of the world. The years of data available for the full dataset vary by country; however, most of the 2000s and early 2010s are covered in most cases (table 1). This information has been gathered as part of the World Bank Exporter Dynamics Database. ${ }^{3}$

2 Information only available for three countries.

3 See Fernandes, Freund, and Pierola (2016) for a detailed description of the data and the cleaning process. A "consolidated" product classification that takes into account the transformations made to product codes according to the Harmonized System (HS) classification throughout the years was employed. In addition, in order to mitigate the risk of including transactions that correspond to shipments of samples or personal belongings, the observations corresponding to exporters that, in a given year, had total sales below \$1,000, were dropped. Also dropped were all the observations belonging to chapter 27 according to the HS classification mineral fuels, oils and products of their distillation, etc. Finally, only the subset of HS codes at six digits that correspond to manufacturing codes according to the International Standard Industrial Classification (ISIC) Revision 3 (chapters 15 to 37) were kept. 
Table 1. Sample and Summary Statistics

\begin{tabular}{|c|c|c|c|c|c|c|}
\hline Country & $\begin{array}{l}\text { Period } \\
(1)\end{array}$ & $\begin{array}{c}\text { No. firms } \\
\text { (2) }\end{array}$ & $\begin{array}{c}\text { Total exports } \\
\text { (USD millions) } \\
\text { (3) }\end{array}$ & $\begin{array}{l}\text { Median value } \\
\text { per exporter } \\
\text { (USD) } \\
\text { (4) }\end{array}$ & $\begin{array}{l}\text { Average value per } \\
\text { exporter (USD } \\
\text { millions) } \\
\text { (5) }\end{array}$ & $\begin{array}{l}\text { Share of top five } \\
\text { firms in total } \\
\text { exports (\%) } \\
\text { (6) }\end{array}$ \\
\hline Albania (ALB) & $2005-2012$ & 1,563 & 1.0 & 40,500 & 0.6 & 22 \\
\hline Bangladesh (BGD) & 2006-2013 & 6,078 & 18.0 & 367,841 & 2.9 & 4 \\
\hline Bolivia (BOL) & 2007-2012 & 673 & 1.6 & 78,146 & 2.2 & 52 \\
\hline Botswana (BWA) & 2006-2013 & 1,123 & 1.0 & 10,486 & 0.9 & 70 \\
\hline Bulgaria (BGR) & 2002-2006 & 11,091 & 7.9 & 26,952 & 0.7 & 19 \\
\hline Cameroon (CMR) & 2002-2006 & 580 & 0.6 & 31,814 & 1.1 & 37 \\
\hline Chile (CHL) & $2005-2012$ & 5,365 & 36.0 & 40,005 & 6.7 & 43 \\
\hline Colombia (COL) & 2007-2013 & 7,107 & 11.6 & 53,083 & 1.6 & 19 \\
\hline Costa Rica (CRI)* & $2005-2012$ & 2,191 & 6.9 & 30,721 & 3.1 & 43 \\
\hline Croatia (HRV) & 2007-2012 & 7,696 & 9.8 & 27,824 & 1.2 & 17 \\
\hline Dominican Republic (DOM) & 2006-2013 & 1,818 & 4.9 & 44,097 & 2.7 & 24 \\
\hline Ecuador (ECU) & 2006-2013 & 2,066 & 3.2 & 29,477 & 1.6 & 22 \\
\hline Egypt (EGY) & 2007-2012 & 6,189 & 15.1 & 96,395 & 2.5 & 12 \\
\hline El Salvador (SLV) & 2002-2009 & 2,219 & 3.4 & 27,479 & 1.6 & 24 \\
\hline Georgia (GEO) & $2005-2012$ & 1,562 & 0.9 & 27,723 & 0.7 & 44 \\
\hline Guatemala (GTM) & $2006-2013$ & 3,390 & 5.0 & 32,625 & 1.5 & 19 \\
\hline $\operatorname{Iran}(\operatorname{IRN})$ & $2006-2010$ & 9,275 & 11.4 & 95,967 & 1.3 & 35 \\
\hline Jordan (JOR) & $2007-2012$ & 2,025 & 4.4 & 67,892 & 2.1 & 31 \\
\hline Kyrgyzstan (KGZ) & 2007-2012 & 608 & 0.5 & 49,600 & 0.9 & 48 \\
\hline Lebanon (LBN) & $2008-2012$ & 4,393 & 2.4 & 39,978 & 0.5 & 19 \\
\hline Madagascar (MDG) & 2007-2011 & 948 & 0.8 & 22,372 & 0.8 & 32 \\
\hline Mexico (MEX) & 2000-2007 & 25,182 & 161.8 & 39,312 & 6.4 & 15 \\
\hline Morocco (MAR)* & 2006-2013 & 4,286 & 12.9 & 73,885 & 3.0 & 30 \\
\hline Pakistan (PAK) & $2003-2010$ & 13,174 & 14.7 & 59,875 & 1.1 & 6 \\
\hline Paraguay (PRY) & 2007-2012 & 554 & 1.2 & 195,160 & 2.2 & 48 \\
\hline Peru (PER)* & $2006-2013$ & 5,333 & 11.0 & 49,021 & 2.0 & 35 \\
\hline Romania (ROU) & 2007-2011 & 9,125 & 40.0 & 259,879 & 4.4 & 15 \\
\hline Senegal (SEN) & 2008-2012 & 588 & 1.0 & 69,383 & 1.7 & 51 \\
\hline South Africa (ZAF) & $2005-2012$ & 18,726 & 36.3 & 36,462 & 1.9 & 19 \\
\hline Tanzania (TZA) & 2005-2012 & 1,183 & 0.6 & 21,804 & 0.6 & 21 \\
\hline Uruguay (URY) & $2005-2012$ & 1,327 & 2.5 & 38,041 & 1.9 & 21 \\
\hline Zambia (ZMB) & 2004-2011 & 832 & 3.9 & 18,795 & 4.4 & 82 \\
\hline
\end{tabular}

Source: Exporter-level data obtained from Exporter Dynamics Database project.

Note: The averages shown in columns (2)-(6) are annual averages for the period/years reported in column (1).

Given the focus of the paper on individual firms, eight countries (mostly in Africa) with less than 500 firms are excluded. ${ }^{4}$ If those countries were included, the importance of superstars is even more pronounced.

To assess the quality of the data, the total values obtained from aggregating the customs data at the country level were compared with the total values obtained at the country level from the UN Comtrade database. The years in which the total values obtained from the customs data which represented less than 70 percent or more than 130 percent of the total values obtained from Comtrade aggregates were dropped. The complete list of countries and years for which data are excluded for reliability or completeness concerns and the comparison with Comtrade data can be found in appendix A2.

Table 1 also reports summary statistics on the number of firms and firm size, using annual averages for the years used for each country. The number and size of exporters varies significantly across

4 For a country like Timor-Leste, the smallest country excluded, with 15 exporting firms, the top 5 is a large share of the total. 
countries. Within countries, there is also a large difference between the median and the mean values per exporter-the mean values are, on average, 50 times larger than the median values per exporter. This difference reflects the highly skewed distribution of the size of firms, which is also confirmed by the considerable share of total exports that is held by the top five firms in most countries. On average the top five firms account for nearly one-third of exports, ranging from 4 percent in Bangladesh to 82 percent in Zambia.

While the full dataset contains information for 32 developing countries, it is worth noting that in this paper we conduct two different exercises: one that decomposes export growth by type of firm (top five firms versus non-top five), and another that tracks the origins of the top five firms. For the growth accounting exercise, the five-year sample of 32 countries is reduced to 24 countries to exclude those with zero or negative aggregate export growth during the five-year period analyzed in each country. The countries with near zero growth are excluded when computing the contribution to growth because the calculation requires putting total growth in the denominator; their contributions balloon when growth is near zero. For countries with negative aggregate growth, superstars tend to buck the trend and have slow but positive growth, suggesting that superstars also serve as a buffer in hard times. A period of eight years of consecutive data is also covered, in which case the sample of 18 countries is further reduced to 17, for the same reason just described. The details of these subperiods and reduced samples used in each type of exercise are presented in appendix A3. In both the five-year sample and the eight-year sample, the period selected corresponds to the latest period with data available for five and eight consecutive years in each country, respectively.

When using the data for examining firm-level growth or churning over time, the identifier codes associated with individual firms may change, for example because of a tax code change or an acquisition. A filter to match the entrants with the exiting firm is used to control for the possibility that such a code change would result in the false exit of one firm and the entry of another firm. The following three characteristics of entering (and exiting) firms are used to help match them: the year of entry (or exit), the total value of exports, and the main product exported. The entrants are then matched with exiters according to three criteria: (i) The entry happened not more than one year before or after the exit (the entry is allowed to happen the year before exit because there may be a short period when both export codes are used). (ii) The total exports of the entrant in the year after entry are not more than double or less than one-half of exports of the exiting firm in the year before exit. The year before exit and the year after entry are used to avoid matching partial year exports. (iii) The top HS six-digit product of the entrant must be the same as the top product of the exiting firm (on average the top product is 85 percent of exports). Using the raw data, there are 40 new superstar firms. Employing the filter, there are seven cases (17.5 percent) of likely code changes. For these seven firms, the data of the exiting and new firms are merged, and firms recoded from new to incumbents. The evidence presented in all tables on growth and transitions has been adjusted to take this correction into account. ${ }^{5}$

\section{The Role of Superstars}

The top five firms within each country-defined as of the last year in each sample-are the export superstars of this analysis. They are an extraordinary group. Regardless of the sample used, whether the five or the eight-year sample, these few firms account for a disproportionately large share of exports-nearly one-third on average within the five-year sample and over a quarter of exports within the eight-year sample. And their contribution to export growth is even larger-47 percent of export growth on average

5 Note that the results on the contribution of superstars to growth and diversification are stronger if this adjustment is not made. For example, when calculating an individual firm's contribution to growth, it will be greater if the initial year is at zero. The results on transitions are also stronger, with new firms starting very large. 
Figure 1. Top Five Firms' Average Share in Exports and Export Growth (percent)

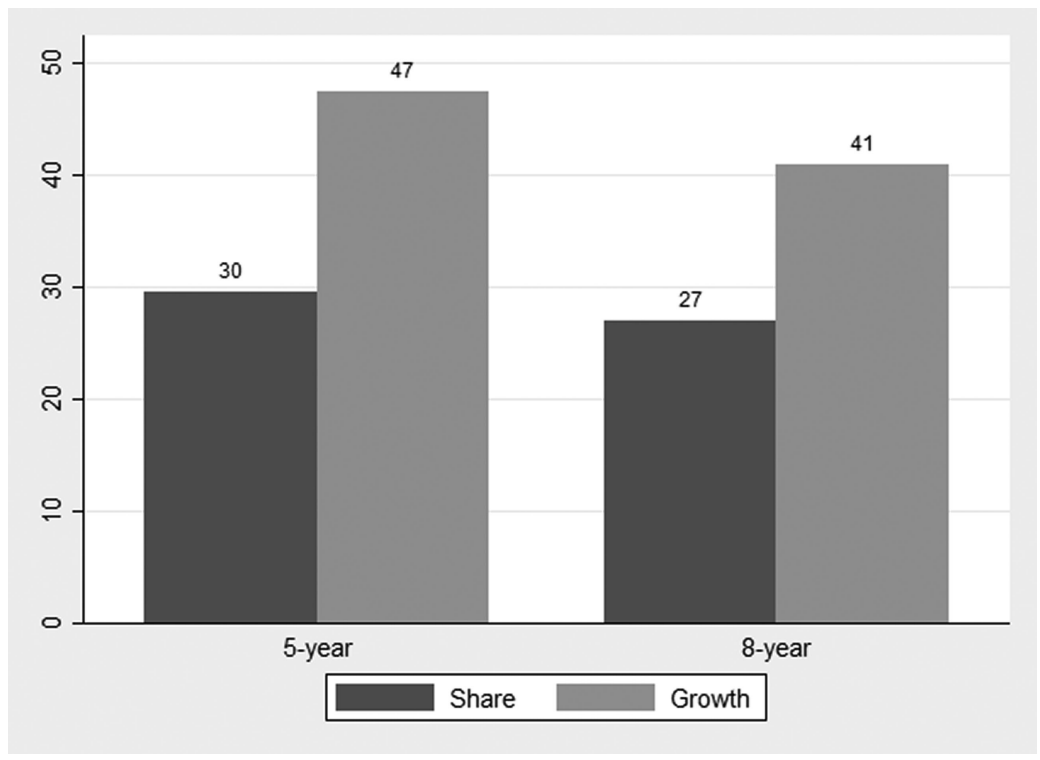

Source: Authors' analysis based on exporter-level data collected for the Exporter Dynamics Database project.

Note: Average for the latest five-year and eight-year periods of consecutive data for each country.

using the five-year sample and 41 percent over an eight-year period (fig. 1). ${ }^{6}$ This section explores their role in explaining trade growth and diversification.

The advantage of focusing on end-of-period superstars is that their history can be examined to learn where they came from and how they have contributed to a country's recent export growth experience. As the main purpose of this paper is to highlight the importance of a few firms, and this definition is simple, it is used throughout. A concern with defining export superstars at the end of the sample is that firm size and recent growth are likely to be positively correlated because current size incorporates previous growth, some of which happened in recent years. However, given that the focus is on the contribution to growth and diversification of individual firms, this concern is less relevant than if the focus were on how growth varies across the distribution, split by percentiles. Still, it is worth noting that results on export growth are qualitatively similar if average firm size over the period is used (see footnote 8 ). In addition, the statistics are complemented with regression analysis that examines the relationship between changes in concentration in the top five firms (where the firms can change over time) and export growth.

Figure 2 shows the contribution of individual firms to total export growth over five years (panel a) and over eight years (panel b). ${ }^{7}$ The horizontal axis records the rank of each firm sorted from largest $($ rank $=1)$ to smallest, for the top five firms at the end of the period. The vertical axis shows the firm's average contribution to export growth across countries. In the five-year sample, on average, the top firm alone is responsible for 20 percent of export growth and the second firm for about 9 percent. In the eight-year sample, the largest five firms contribute significantly to export growth, with the top firm alone

6 The share in exports reflect the average share across countries during the last year, fifth year, and eighth year in each sample. The contribution to growth is calculated for each country between the first and the last year in each sample. The number in fig. 1 reflects the average contribution across countries, where for each country, the firm contributions sum to one.

7 See appendix A3 for details on the group of countries and periods used for this calculation. 
Figure 2. Average Contribution to Export Growth, by Firm

(a) Five-year sample;

(b) Eight-year sample
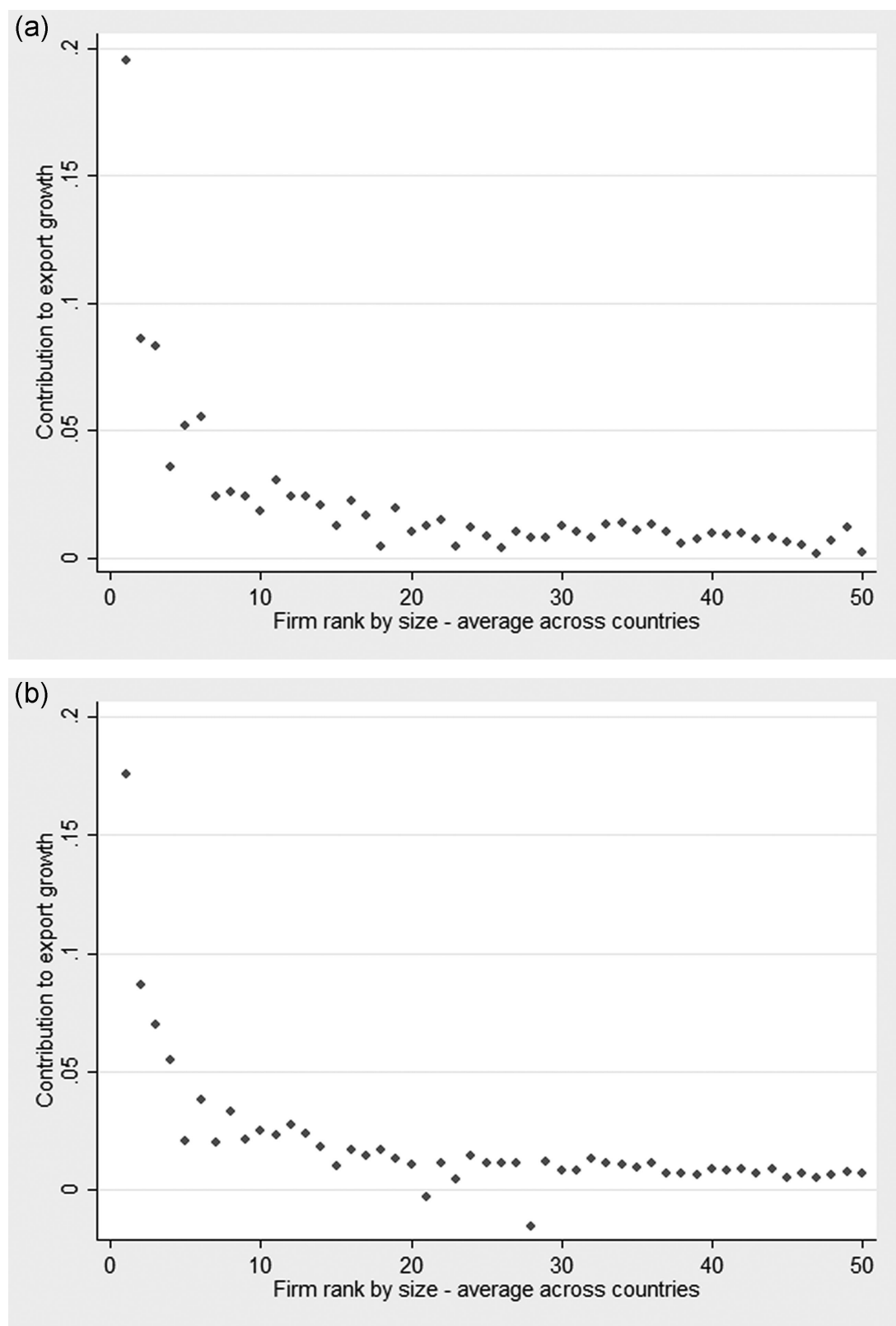

Source: Authors' analysis based on exporter-level data collected for the Exporter Dynamics Database project.

Note: Average contribution to total export growth by the largest firms, when firms are ranked from largest to smallest, using end-of-period size. Panel (a) is five-year growth using the five-year sample of 32 countries. Panel (b) is eight-year growth using the eight-year sample of 18 countries. 
Table 2. Concentration and Export Growth (growth over a period)

\begin{tabular}{|c|c|c|c|c|}
\hline \multirow[t]{2}{*}{ Dep. var.: export growth } & \multicolumn{2}{|c|}{ Five-year growth } & \multicolumn{2}{|c|}{ Eight-year growth } \\
\hline & (1) & $(2)$ & (3) & (4) \\
\hline Change in share of top firm & $\begin{array}{l}0.783 * * * \\
(0.21)\end{array}$ & & $\begin{array}{l}0.984 * * * \\
(0.26)\end{array}$ & \\
\hline Change in share of top five firms & & $\begin{array}{l}1.540 * * * \\
(0.30)\end{array}$ & & $\begin{array}{l}1.196 * * * \\
(0.38)\end{array}$ \\
\hline Constant & $\begin{array}{c}0.291 \\
(0.45)\end{array}$ & $\begin{array}{c}0.283 \\
(0.44)\end{array}$ & $\begin{array}{l}1.774 * * \\
(0.75)\end{array}$ & $\begin{array}{l}1.843 * * \\
(0.76)\end{array}$ \\
\hline Country FE & YES & YES & YES & YES \\
\hline Industry FE & YES & YES & YES & YES \\
\hline Observations & 2,398 & 2,398 & 1,404 & 1,404 \\
\hline R-squared & 0.13 & 0.13 & 0.19 & 0.19 \\
\hline
\end{tabular}

Source: Authors' analysis based on exporter-level data collected for the Exporter Dynamics Database project.

Note: The dependent variable is calculated as the year-to-year log difference of total exports within a country-industry pair. The independent variables are calculated as the year-to-year changes in the shares of the top firm and of the top five firms within a country-industry pair. Robust standard errors in parentheses. $* * * 0<0.01, * p<0.05, * p<0.1$.

typically accounting for about 18 percent of export growth. ${ }^{8}$ What is striking about the graph is the lumpiness of export growth in the superstars: these five firms account for a large share of export growth.

The greater contribution of the largest firms to export growth as compared with export volume helps to explain why exports grow as concentration increases. The share in exports of the top five firms increases, on average, by 7 percentage points in the five-year sample and 10 percentage points in the eight-year sample. One potential explanation is that countries tend to specialize in more capital-intensive production as they develop, and thus increasing concentration could be a result of a shift from less concentrated industries like apparel to more concentrated ones like machinery. To control for industry and country effects, the following fixed-effects model is estimated:

$$
d \ln \text { exports }_{c i}=\alpha_{c}+\alpha_{i}+\beta d \text { share }_{c i}+\varepsilon_{c i},
$$

where $d \ln$ exports $_{c i}$ is export growth in a country-industry pair $(c i)$ between the first and the last year in each sample, $\alpha_{c}$ are country-fixed effects, $\alpha_{i}$ are industry effects at the HS two-digit level, dshare $e_{c i}$ is the change in the share of the top firm (or top five firms) in the country-industry from the last to the first year in each sample, and $\varepsilon_{c i}$ is the error term. The country effects pick up the fact that some countries have overall faster export growth, perhaps because of trade liberalization or other country-specific factors. The industry effects pick up the fact that some industries grow faster than others, for example because of global demand shocks. In some specifications, using annual data, country-industry effects are also included to examine export growth and concentration within country-industries. The regression is estimated on the full five-year sample of 32 countries and also on the full eight-year sample of 18 countries.

Controlling for country and industry fixed effects, a 1 percentage point increase in the share of the top firm in an industry is associated with 0.8 percent faster export growth over five years and 1 percent faster export growth over eight years. Similarly, a 1 percentage point increase in the share of the top five firms is associated with more than 1 percent faster export growth (table 2).

8 Using the end-of-period size could bias the results towards a negative relationship between contribution to growth and rank. The purpose of the chart, however, is not to show the slope but to show the magnitude of the contribution to aggregate export growth of the superstars. The difference between the 5 firms in the top of the distribution and all others is visually distinct. If average size over the period is used (as Davis, Haltiwanger, and Shuh [1996] do for employment growth), the importance of the top 5 firms remains relatively large. In particular, the top 5 firms account for 33 percent of total export growth using average firm size, as compared with 47 percent using end-of-period firm size in the 5 -year sample, and 26 percent and 41 percent, respectively, in the 8-year sample. 
Using the annual data, year-to-year growth is estimated on annual changes in the shares of the top firms, including country-industry effects for robustness. This specification examines whether within countryindustries export growth is correlated with the share of the superstars. Table 3 shows these results. Columns (1) to (4) present the results using annual variations within the five-year sample, columns (5) to (8) within the eight-year sample and columns (9) to (12) include annual variations using all 32 countries and all years available. The results are qualitatively the same and robust to including country-industry fixed effects. In terms of magnitude of the coefficients, the correlation is even higher for the top five firms in all specifications.

Overall the results imply that rapid export growth is correlated with more concentration in the top five firms. The results do not speak to causality. It could be that increased foreign demand or trade liberalization allows large firms to grow more, relatively, or that productivity shocks to large firms have bigger effects on exports. In either case, however, the positive correlation between export growth and concentration is consistent with the existing evidence of the importance of allocative efficiency in export growth. Allocative efficiency improves if more productive firms account for a larger share of exports, which would happen if the larger and more productive firms take a bigger share of exports because of demand from abroad or because of productivity shocks. Fernandes, Freund, and Pierola (2016) also find evidence that export concentration in the top 5 percent tends to increase with exports. The results in this paper take this a step further, showing that concentration in the top five firms, and even in the top firm, increase as a country's exports grow. The results are consistent with the evidence on the distribution of firm sizes from the macroeconomic literature. Hsieh and Klenow (2009) find that, as countries develop and allocative efficiency improves, the distribution of the size of firms gets wider, with a few extraordinarily large firms. Di Giovanni and Levchenko (2012) find that trade opening makes the largest firms more important, and hence volatility increases as small economies open to trade.

Next, the contribution of the top five firms to overall export growth is studied, disentangling it by margin of trade-intensive and extensive-and using the five-year period sample mentioned previously. In this growth accounting exercise, the extensive margin is defined in two alternative ways. First, "new" products and "new" markets are defined by considering a country perspective. This definition allows us to determine which types of firms help countries expand into new products or new markets.

In this case, exports are aggregated at the country-year level and products/markets are considered "new" if they are exported/covered in year 5 but were not exported/covered in year 1 . This definition leads to three components within the extensive margin: new products in new markets (NPND), new products in old markets (NPOD), and old products in new markets (OPND). The intensive margin would only include the exports of old products in old markets. The results are presented in fig. 3. Superstars account for 47 percent of total export growth and 48 percent of the growth attributed to the intensive margin. Regarding the extensive margin, they account for a third of the growth due to this margin (fig. 3 panel [a]). Looking at the different components within the extensive margin, it is worth noting that most of the growth accounted for by the extensive margin is due to the exports of new products in old destinations followed by the exports of new products to new destinations. The share of pure market diversification is negative (fig. 3 panel $[\mathrm{b}])^{9}$

9 An alternative way to evaluate superstars' role in the extensive margin is to look at the share of the total number of new product-market combinations that is from superstars. On average, 2.4 percent new product-market combinations across countries are from the top 5 firms. Although the fraction is small as compared with the value of the extensive margin, it is a count measure and therefore should be compared to superstars' share in the total number of exporters. Superstars make up on average only 0.3 percent of exporting firms, so their 2.4 percent share of new product-markets implies that a superstar starts 8 times as many new product-markets as the average exporter. The much higher share of the value of the extensive margin indicates that the new-product markets of superstars include a disproportionate share of very large flows. 


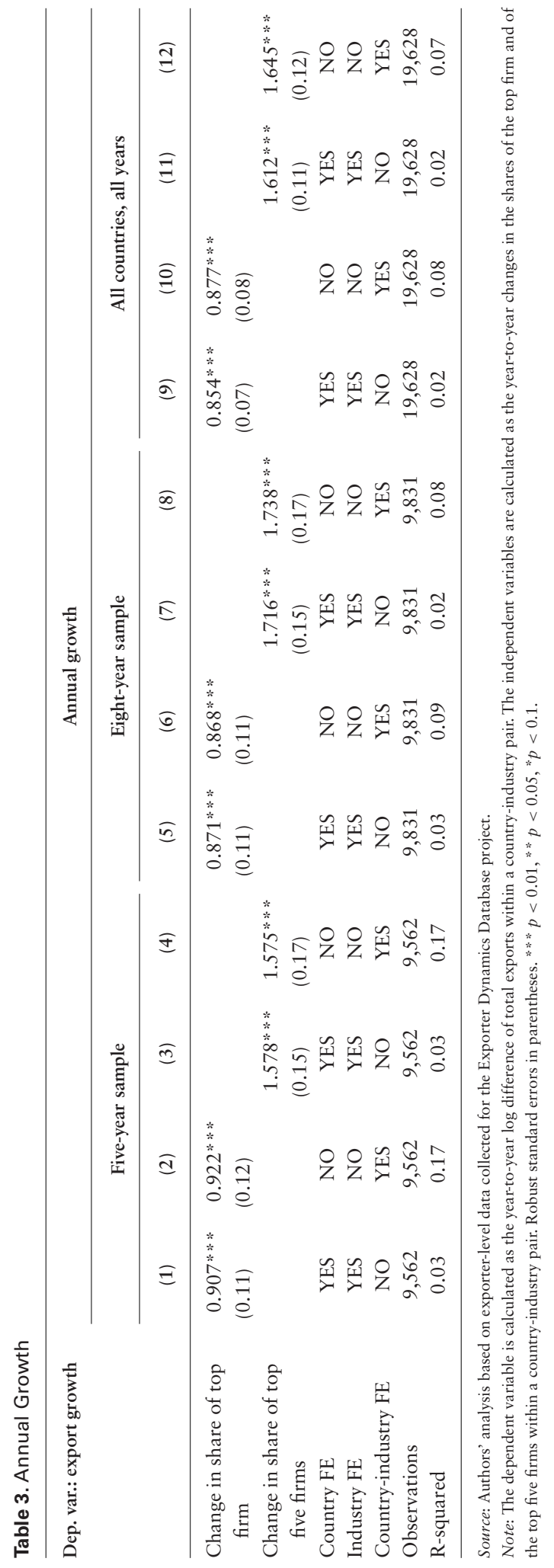


Figure 3. Top Five's Contribution to Export Growth: Extensive Margin Defined at the Country Level, Five-year Sample (percent) (a) Share in export growth by margin of trade

(b) Share in export growth within the extensive margin
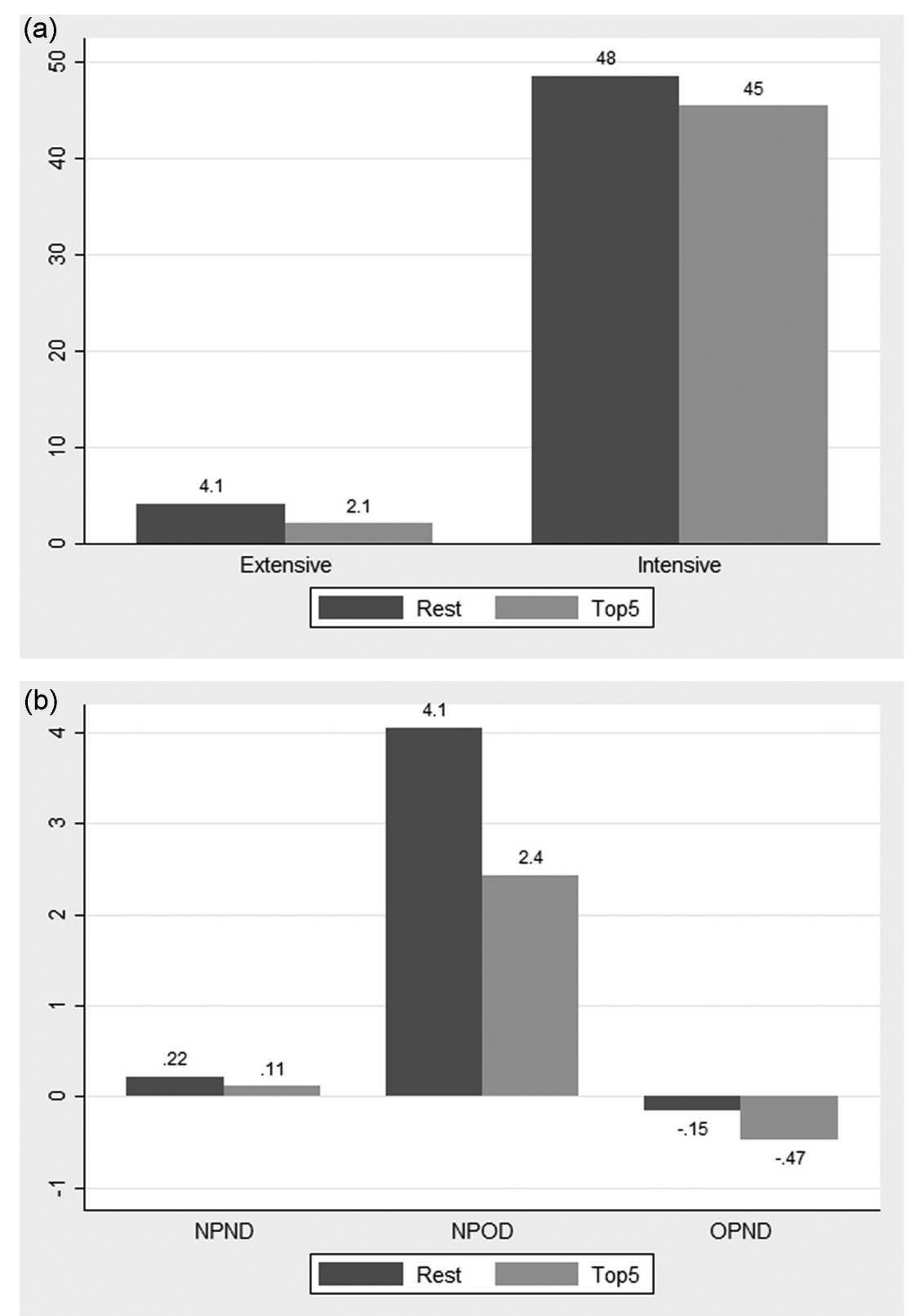

Source: Authors' analysis based on exporter-level data collected for the Exporter Dynamics Database project.

Note: Average export growth for the five-year period of consecutive data for each country. NPND $=$ new product - new destination, NPOD $=$ new product - old destination, OPND = old product-new destination. 
The second definition of the extensive margin exploits the firm-level nature of the data. This specification answers the question of what types of new firms are important for export growth and how common it is for firms to expand into new markets or products.

In this case, the extensive margin is composed of new firms and then new products and new markets for the incumbent firms. For this, firms are first identified as "new" if they were not in the sample in year 1 but are exporting in year 5. By construction, all the products exported and markets covered by these firms are "new" but they are accounted for within the "new firm" component of the extensive margin. Then, for the incumbent firms, a product is considered "new" if the firm did not export it in year 1 but did so in year 5. Similarly, the same identification is applied for "new" markets. Thus, the extensive margin has four components in this case: exports of new firms, and exports of NPND, NPOD, and OPND; these last three components are possessed only by incumbent firms. The intensive margin would only include the exports by incumbent firms of old products in old markets. Figure 4 panel (a) shows the top five firms' contribution to overall export growth by margin of trade, and fig. 4 panel (b) looks at the different components within the extensive margin. The contribution of superstars to overall export growth remains the same at 47 percent. Their contribution within the extensive margin, however, is larger because the growth from "new" firms was included as part of the intensive margin in the previous definition. ${ }^{10}$ The average contribution from these "new" superstars is in fact the largest component of the extensive margin's share in export growth, followed by the growth from product diversification by the incumbent firms.

The results from both growth accounting exercises reveal that, beyond their role in overall export growth, the contribution of superstars is important in explaining the growth that originates from firm churning and export diversification, especially product diversification.

\section{Origin of Superstars}

This section explores diverse features characterizing the beginnings of superstars. First, the top five firms are identified, based on the last year in each sample; their presence is then tracked from their first year in the sample so we can learn more about their size at their start as exporters. Of the top five firms from year 5, 71 percent were already large (within the top 1 percent) five years earlier (fig. 5 panel [a]). A sizable share of them, 13 percent, are "new" in the sense that they were not in the sample five years earlier. It is extremely rare to find top five firms that emerge from the bottom half of the distribution of the size of firms. The evidence is similar if the same analysis is conducted using the eight-year sample instead. Of the top five firms, 60 percent defined in the eighth year were large, within the top 1 percent, eight years earlier. Almost 30 percent of them did not exist in year 1 and only 1 percent of them were in the bottom 50 percent of the size distribution in the first year (fig. 5 panel [b]).

Figure 6 explores the "new" top five firms-those exporters that do not exist in the first year but grow to reach the top five by the last year in each sample. It records, for each new exporter, the percentile group in the size distribution in their entry year. Using the five-year sample, 35 percent of the superstars "born" within the period were born straight into the top five exporters; 55 percent were born in the top 1 percent. Only 5 percent of future superstars were born in the bottom half of the distribution (fig. 6 panel [a]). The results for the 18 countries with data for eight consecutive years of data also reveal that one-third of the top five firms were born in the top 1 percent (fig. 6 panel [b]). The evidence indicates that the top five firms are born large and also stay large or exit; shrinking is rare. There is an up-or-out phenomenon. The fact that superstars rarely originate from the bottom half of the distribution does not mean that they do not need to grow. Given the extraordinary skewness of the distribution of the size of exporters, becoming

10 Results produced using the alternative 8-year sample are presented in appendix A1. Although superstars' contribution decreases with this sample, their role in export diversification remains important. 
Figure 4. Top Five's Contribution to Export Growth: Extensive Margin Defined at the Firm Level, Five-year Sample (percent)

(a) Share in export growth by margin of trade

(b) Share in export growth within the extensive margin
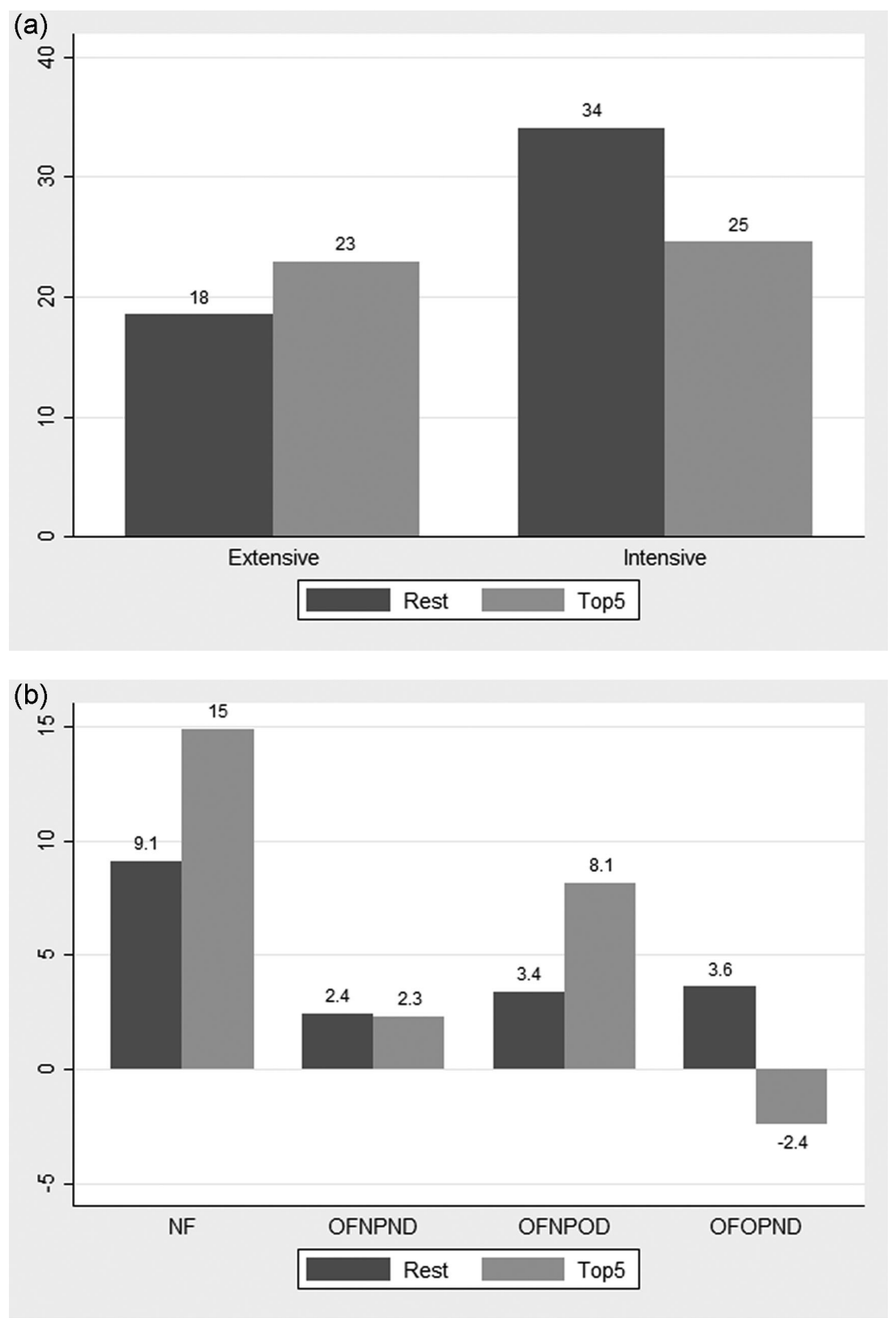

Source: Authors' analysis based on exporter-level data collected for the Exporter Dynamics Database project.

Note: Average export growth for the five-year period of consecutive data for each country. NF = new firm, OFNPND = old firm-new product-new destination, OFNPOD $=$ old firm—new product—old destination, OFOPND = old firm—old product—new destination. 
Figure 5. Year 1's Size of the Top Five Firms, Defined in the Last Year of Each Sample

(a) Five-year sample

(b) Eight-year sample
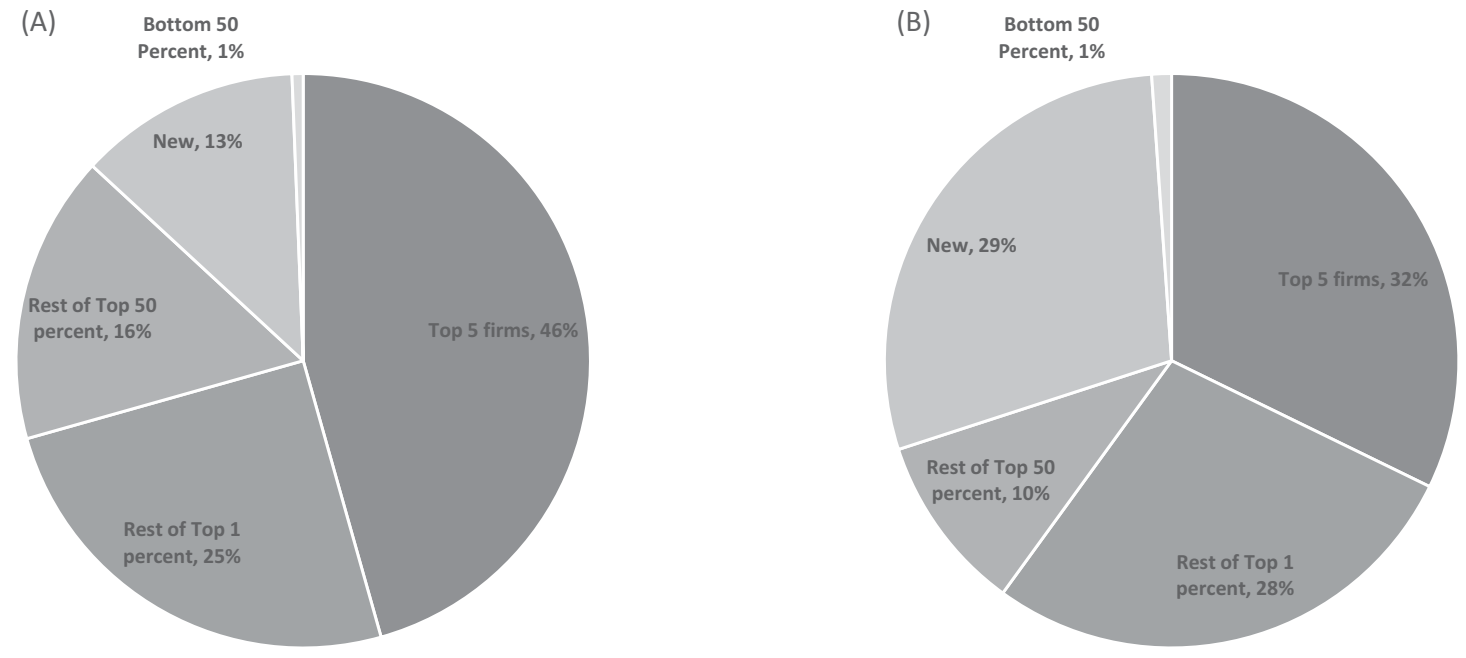

Source: Authors' analysis based on exporter-level data collected for the Exporter Dynamics Database project.

Note: Size distribution of year 5's top five firms, five years earlier in (a) and year 8's top five firms, eight years earlier in (b).

Figure 6. Size Distribution of New Top Five Firms on Entry

(a) Five-year sample
(b) Eight-year sample

(A) Bottom 50

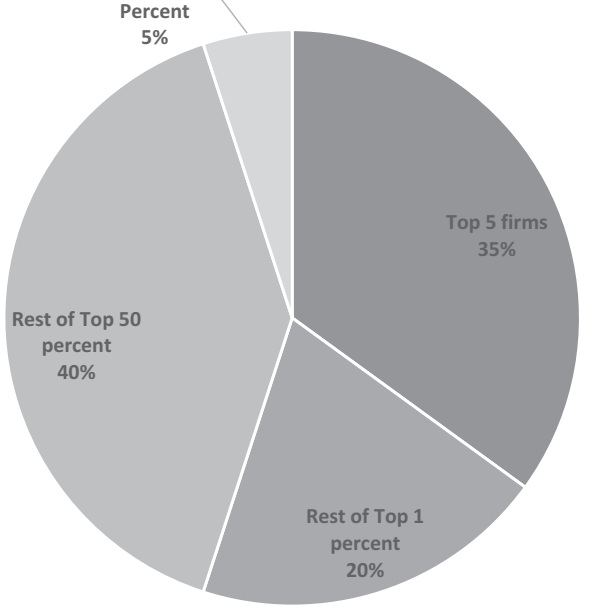

(B)

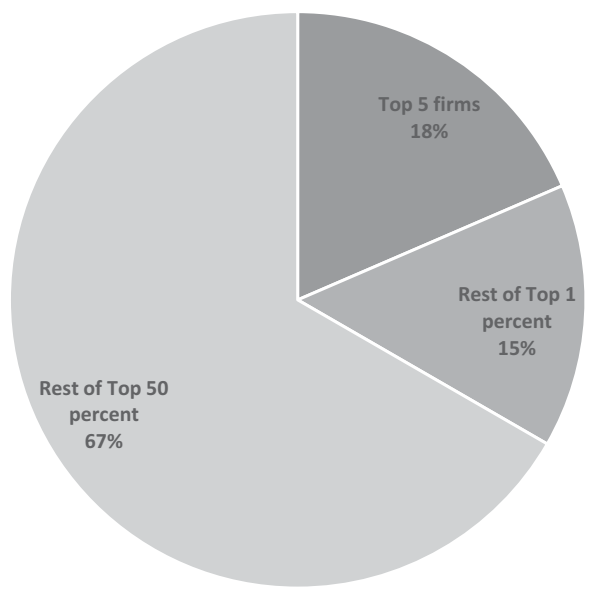

Source: Authors' analysis based on exporter-level data collected for the Exporter Dynamics Database project.

Note: Size distribution of the top five firms, defined in the last year of the five-year sample in (a) and in the eight-year sample in (b), upon their entry.

a top five firm still requires superior growth. For example, a firm born at the cutoff for the top 1 percent of exporters still needs to grow 7.3 times, on average, to become a superstar.

The results show that most of today's largest firms were already top five or large firms in the past or were new firms that became large-i.e., small exporters that grew slowly into the top five are rare. The speed at which the firms that entered into the sample sometime after the beginning of the period became 
Figure 7. Number of Years to Become Top Five Firm among the "New" Superstars in the Five-year Sample

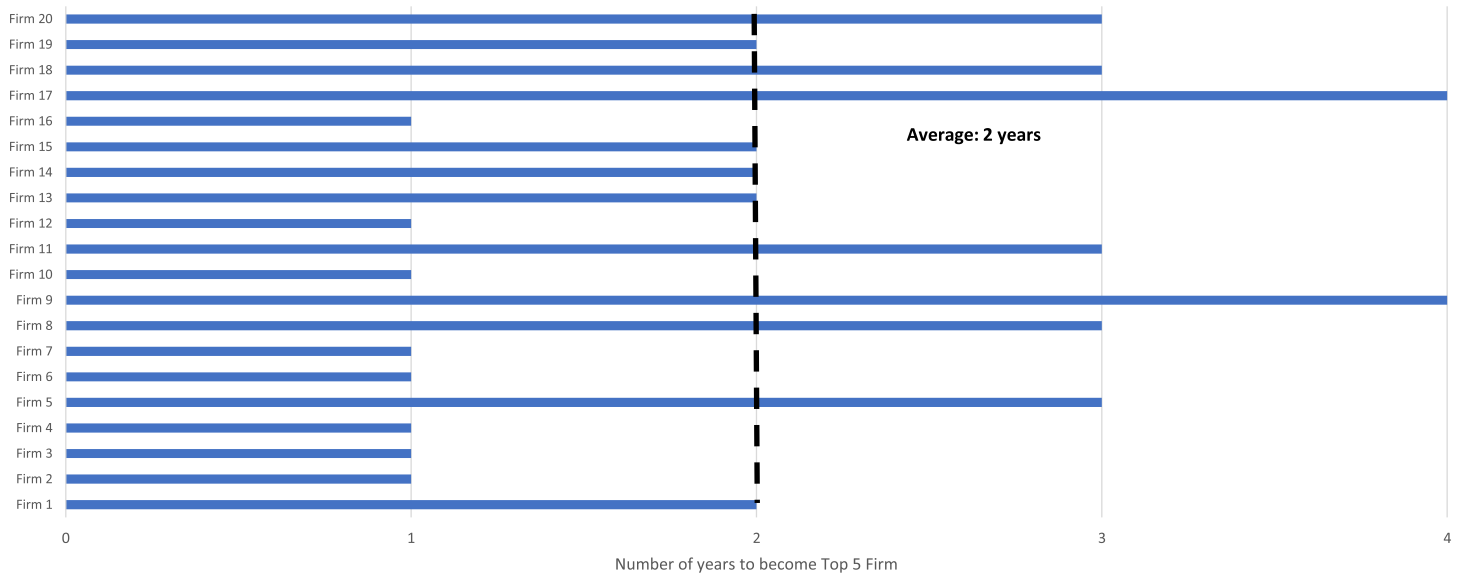

Source: Authors' analysis based on exporter-level data collected for the Exporter Dynamics Database project.

Note: Includes the top five firms in year 5 that were not in the sample in year 1.

top five firms is also analyzed, using the five-year sample. For that purpose, the number of years that each firm took to become a top five firm, after they first appear in the sample, is counted. On average, across the 20 "new" top five firms in year 5, the pace was two years across countries (fig. 7). Again, these results reflect the fact that patterns are similar, even in countries located in different regions, and that the top five firms of the present were born relatively large and grew fast. The short gestation period could be because the data only concern a relatively short period, so the firms must grow fast. Using the eight-year panel for 18 countries, which would allow a longer gestation, there are 17 new superstar firms over the period. The average number of years it takes for a new superstar to become one is also two years, again suggesting that superstars grow quickly.

\section{Superstar Characteristics}

Unfortunately, the data do not allow observations of superstars before they begin exporting, as there is no information on domestic sales or how they became exporters. However, given that in nine countries it was possible to identify the superstars by name, the origins of their top five firms were examined. Table 4 presents a summary of the findings from this investigation. ${ }^{11}$ In all nine countries, the overwhelming majority of the top five firms are either producers or manufacturers; only Colombia and Madagascar have but a few traders. ${ }^{12}$ The absence of traders among the largest firms is consistent with evidence from Bernard et al. (2010) and Ahn, Khandelwal, and Wei (2011), who find that the most productive firms or largest firms export directly.

11 This investigation was conducted via searches on the companies' web sites. Information for all top 5 firms could be found in all nine countries.

12 There could be many producers that export, but an intermediary firm that coordinates the process, consolidates the production and exports it as one firm, could appear in the data as a large exporter. This would have implications about the interpretation of the results in terms of accurately capturing firm-level production for the export sector. For the purpose of this investigation, a firm is defined as a trader if it acts as an intermediary, without engaging in any type of transformation of the merchandise traded. If a firm engages in packaging or basic processing of goods (for example sorting or drying), that firm is considered a "transformer" and is not counted as a trader. 
Table 4. Features of the Top Five Superstars (percent)

\begin{tabular}{|c|c|c|c|c|}
\hline & \multicolumn{2}{|c|}{ Type of exporter } & \multicolumn{2}{|c|}{ Ownership } \\
\hline & Producer & Trader & Foreign & Domestic \\
\hline Botswana, 2013 & $100 \%$ & $0 \%$ & $60 \%$ & $40 \%$ \\
\hline Bulgaria, 2006 & $100 \%$ & $0 \%$ & $100 \%$ & $0 \%$ \\
\hline Colombia, 2015 & $60 \%$ & $40 \%$ & $40 \%$ & $60 \%$ \\
\hline Costa Rica, 2014 & $100 \%$ & $0 \%$ & $100 \%$ & $0 \%$ \\
\hline Jordan, 2009 & $100 \%$ & $0 \%$ & $80 \%$ & $20 \%$ \\
\hline Madagascar, 2011 & $80 \%$ & $20 \%$ & $100 \%$ & $0 \%$ \\
\hline Pakistan, 2010 & $100 \%$ & $0 \%$ & $0 \%$ & $100 \%$ \\
\hline Peru, 2013 & $100 \%$ & $0 \%$ & $60 \%$ & $40 \%$ \\
\hline Tanzania, 2012 & $100 \%$ & $0 \%$ & $60 \%$ & $40 \%$ \\
\hline
\end{tabular}

Source: Phone interviews to top 5 companies and information contained in their websites.

Note: Characteristics of the top five firms in nine countries where firms can be identified by name. The years used in the identification of firms were the last year of data available in each country, except in the case of Jordan where the year used was 2009 instead of 2012. A firm is defined as a trader if it only acts as an intermediary, without engaging in any activity that implies any type of transformation of the merchandise traded.

Superstars are also linked to the presence of foreign capital and tend to grow quickly into exporters. ${ }^{13}$ On average, 67 percent of superstars are more than 50 percent foreign owned.

Superstars operate in many industries. Using the complete sample including all countries, the industries (by HS two-digit codes) in which superstars operate is evaluated. Regardless of the sample looked at, whether the five-year or eight-year sample, superstars operate in a wide range of industries. There are two sectors in which their presence is always important: metals, and textiles and apparel. For example, using the eight-year sample, each of these two sectors holds 21 percent of superstars. Their presence is spread more evenly between other sectors, such as foodstuffs, chemicals, transportation, and machinery (10 percent each on average).

In earlier work, for three countries-Jordan, Peru, and Tanzania-phone interviews with managers in the largest firms (covering the top 1 percent of exporters) and online research using the firms' sites were conducted to establish the age of the firm when exporting began. Of the largest firms, 68 percent began exporting within two years of establishment, on average, across these three countries (Freund and Pierola 2012). ${ }^{14}$ The interviews also confirmed the high share of foreign ownership. The case of successful domestic firms that turn to export markets and enter the top five over time is a rare event.

To sum up, the group of top five firms is a unique group of firms. They explain most of the export growth and diversification observed across countries, and they are born big or very rapidly become so. The cases of small firms making it to the top are rare.

\section{Robustness: Results on the Top 1 Percent of Exporters}

This paper focuses on the top five firms to highlight that individual firms matter and to understand where they come from. It might be the case that large firms defined more broadly behave differently. However, a parallel analysis to the one presented in previous sections, examining the top 1 percent of exporters, reveals the same patterns (see Freund and Pierola 2012). In particular, the top 1 percent account for 54

13 The importance of foreign capital among the group of top 5 firms is consistent with the work of Helpman, Melitz, and Yeaple (2004). They develop a model to explore the role of firm heterogeneity in explaining the structure of trade and find that within exporters, only the most productivethe top five firms in the context of this paperengage in FDI. These firms, most likely superstars in source countries, are the ones creating superstars in "home" countriesthe countries observed in this analysis. Freund and Moran (2017) find that new foreign firms in Costa Rica, Malaysia, and Morocco grew into export superstars, promoting export diversification, by investing in new industries.

14 The percent of firms that became exporters within 0-2 years of being established was 81 percent in Jordan, 71 percent in Peru and 53 percent in Tanzania. The response rate on this question, per country was 84 percent for Jordan, 84 percent for Peru and 94 percent for Tanzania. 
percent of exports in manufacturing, 64 percent of the export growth in this sector, and more than half of the growth due to the extensive margin. The top 1 percent of exporters was generally large in the past or was born large. Overall these results confirm that large and very large firms do not seem to originate as small exporters.

\section{Conclusions}

Using a dataset containing firm-level information on exports from a diverse group of developing countries, this paper contributes to the literature on the firm-level analysis of trade by providing complementary evidence on the importance and origin of the top five largest exporters in a country.

The top five exporters are part of a unique group. They are larger and more diversified than other firms. Together they account for nearly one-third of export volumes, and nearly half of growth over five years. They also contribute disproportionately to the extensive margin; almost all of this share is accounted for by their growth in the exports of products that are "new," either from a country or a firm perspective. Superstars are often linked to foreign capital, and many are born to be exporters. The top five firms themselves do not seem to grow as a result of a lengthy process. In fact, they are often born large, and when they are not, it does not take them long to become superstars.

This analysis shows how the top five firms dramatically influence trade, though data limitations prevent exploration as to why this happens, beyond showing that foreign investment plays an important role. Further research is needed to understand the contribution of variation in firm-level technologies (including foreign technology) and increasing returns to scale in explaining why large firms dominate exports.

From a policy perspective, the research underscores the importance of allowing firms to grow large to expand trade. It is important that the business climate is conducive to rapid firm growth and that it does not discriminate against firms of any size. Openness to entry of new firms into exporting is also important, as new exporters account for a large share of export growth. The results also imply that opening to foreign direct investment, in particular, is key to trade growth.

\section{Appendix A1. Top Five's Contribution to Export Growth, Eight-year Sample (percent)}

(a) Extensive margin defined at the country level

(b) Extensive margin defined at the firm level

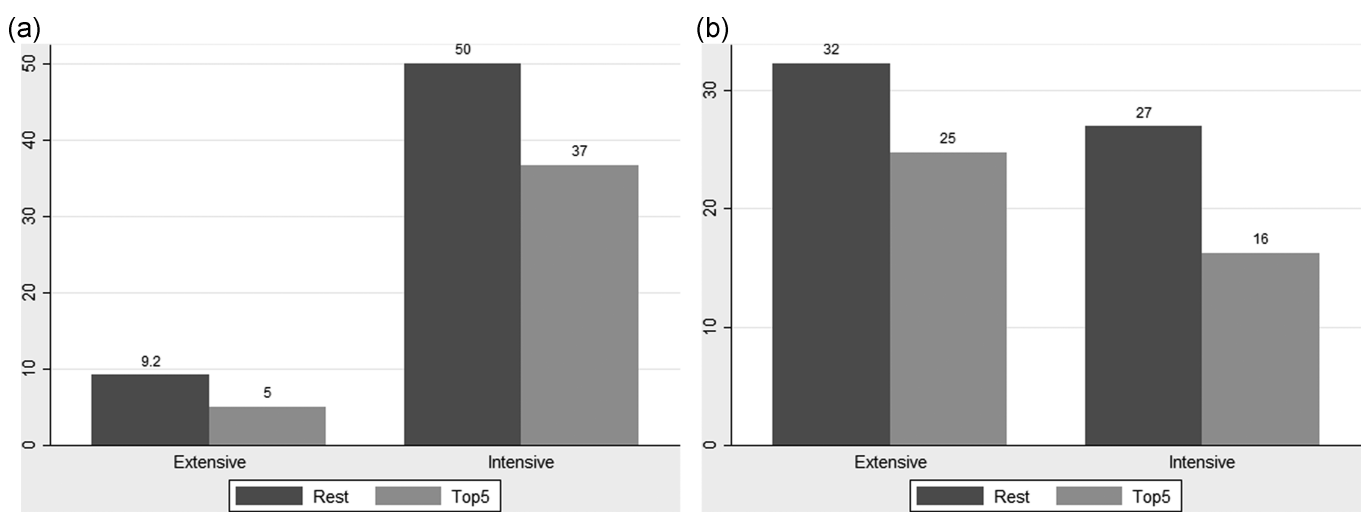

Source: Authors' analysis based on exporter-level data collected for the Exporter Dynamics Database project.

Note: Average export growth for the eight-year period of consecutive data for each country. 
Appendix A2. Countries and Years Dropped from Original Sample: Comparison Ratio between the Data Used in the Paper and Total Trade from Comtrade Data (percent)

\begin{tabular}{|c|c|c|c|c|c|c|c|c|c|c|c|c|c|c|}
\hline Country & 2000 & 2001 & 2002 & 2003 & 2004 & 2005 & 2006 & 2007 & 2008 & 2009 & 2010 & 2011 & 2012 & 2013 \\
\hline ALB & & & & & $108 \%$ & $110 \%$ & $103 \%$ & $102 \%$ & $103 \%$ & $118 \%$ & $111 \%$ & $109 \%$ & $111 \%$ & \\
\hline BGD & & & & & & $96 \%$ & $102 \%$ & $96 \%$ & $99 \%$ & $101 \%$ & $100 \%$ & $99 \%$ & $105 \%$ & $100 \%$ \\
\hline BGR & & $103 \%$ & $105 \%$ & $102 \%$ & $101 \%$ & $98 \%$ & $99 \%$ & & & & & & & \\
\hline BOL & & & & & & & $94 \%$ & $101 \%$ & $100 \%$ & $101 \%$ & $100 \%$ & $100 \%$ & $100 \%$ & \\
\hline BWA & & & & $60 \%$ & $89 \%$ & $96 \%$ & $98 \%$ & $97 \%$ & $87 \%$ & $117 \%$ & $92 \%$ & $92 \%$ & $93 \%$ & $97 \%$ \\
\hline $\mathrm{CHL}$ & & & & $94 \%$ & $94 \%$ & $92 \%$ & $95 \%$ & $96 \%$ & $109 \%$ & $91 \%$ & $95 \%$ & $100 \%$ & $98 \%$ & \\
\hline CMR & $103 \%$ & $104 \%$ & $99 \%$ & $97 \%$ & $94 \%$ & $100 \%$ & $99 \%$ & $100 \%$ & $101 \%$ & $100 \%$ & $99 \%$ & $100 \%$ & $99 \%$ & \\
\hline $\mathrm{COL}$ & & & & & & & & $100 \%$ & $100 \%$ & $100 \%$ & $102 \%$ & $103 \%$ & $102 \%$ & $99 \%$ \\
\hline CRI & $108 \%$ & $107 \%$ & $107 \%$ & $106 \%$ & $106 \%$ & $98 \%$ & $113 \%$ & $105 \%$ & $98 \%$ & $98 \%$ & $105 \%$ & $102 \%$ & $101 \%$ & \\
\hline DOM & & & $66 \%$ & $68 \%$ & $60 \%$ & $65 \%$ & $83 \%$ & $88 \%$ & $95 \%$ & $106 \%$ & $111 \%$ & $104 \%$ & $101 \%$ & $101 \%$ \\
\hline ECU & & & $100 \%$ & $105 \%$ & $104 \%$ & $105 \%$ & $100 \%$ & $108 \%$ & $99 \%$ & $99 \%$ & $99 \%$ & $99 \%$ & $99 \%$ & $99 \%$ \\
\hline EGY & & & & & & & & & $126 \%$ & $96 \%$ & $103 \%$ & $93 \%$ & $102 \%$ & \\
\hline GEO & & & & $98 \%$ & $98 \%$ & $98 \%$ & $97 \%$ & $98 \%$ & $98 \%$ & $112 \%$ & $119 \%$ & $108 \%$ & $127 \%$ & \\
\hline GTM & & & & & & $98 \%$ & $97 \%$ & $97 \%$ & $99 \%$ & $96 \%$ & $96 \%$ & $98 \%$ & $95 \%$ & $100 \%$ \\
\hline HRV & & & & & & & & $100 \%$ & $100 \%$ & $100 \%$ & $100 \%$ & $100 \%$ & $100 \%$ & \\
\hline IRN & & & & & & & $100 \%$ & NA & NA & NA & $100 \%$ & & & \\
\hline JOR & & & & $51 \%$ & $48 \%$ & $56 \%$ & $71 \%$ & $70 \%$ & $76 \%$ & $93 \%$ & $86 \%$ & $77 \%$ & $95 \%$ & \\
\hline KGZ & & & & & & & $100 \%$ & $100 \%$ & $79 \%$ & $107 \%$ & $100 \%$ & $100 \%$ & $100 \%$ & \\
\hline LBN & & & & & & & & & $100 \%$ & $100 \%$ & $100 \%$ & $100 \%$ & $101 \%$ & \\
\hline MAR & & & $100 \%$ & $100 \%$ & $100 \%$ & $100 \%$ & $102 \%$ & $104 \%$ & $99 \%$ & $100 \%$ & $101 \%$ & $95 \%$ & $99 \%$ & \\
\hline MDG & & & & & & & & $97 \%$ & $101 \%$ & $103 \%$ & $117 \%$ & $107 \%$ & $133 \%$ & \\
\hline MEX & $100 \%$ & $98 \%$ & $100 \%$ & $100 \%$ & $100 \%$ & $100 \%$ & $100 \%$ & $100 \%$ & $100 \%$ & $100 \%$ & & & & \\
\hline PAK & & & & $96 \%$ & $95 \%$ & $90 \%$ & $94 \%$ & $97 \%$ & $99 \%$ & $102 \%$ & $101 \%$ & & & \\
\hline PER & $101 \%$ & $101 \%$ & $100 \%$ & $100 \%$ & $101 \%$ & $101 \%$ & $100 \%$ & $100 \%$ & $98 \%$ & $99 \%$ & $101 \%$ & $102 \%$ & $100 \%$ & $99 \%$ \\
\hline PRY & & & & & & & & $89 \%$ & $84 \%$ & $96 \%$ & $96 \%$ & $101 \%$ & $99 \%$ & \\
\hline ROU & & & & & & $100 \%$ & $101 \%$ & $99 \%$ & $98 \%$ & $97 \%$ & $97 \%$ & $98 \%$ & & \\
\hline SEN & $46 \%$ & $56 \%$ & $94 \%$ & $70 \%$ & $66 \%$ & $73 \%$ & $68 \%$ & $70 \%$ & $82 \%$ & $82 \%$ & $73 \%$ & $78 \%$ & $71 \%$ & \\
\hline SLV & & & $104 \%$ & $104 \%$ & $105 \%$ & $105 \%$ & $98 \%$ & $104 \%$ & $113 \%$ & $108 \%$ & & & & \\
\hline TZA & & & & $110 \%$ & $102 \%$ & $102 \%$ & $99 \%$ & $98 \%$ & $94 \%$ & $100 \%$ & $91 \%$ & $96 \%$ & $100 \%$ & \\
\hline URY & & $99 \%$ & $100 \%$ & $99 \%$ & $98 \%$ & $98 \%$ & $96 \%$ & $93 \%$ & $91 \%$ & $86 \%$ & $86 \%$ & $93 \%$ & $87 \%$ & \\
\hline $\mathrm{ZAF}$ & & $127 \%$ & $135 \%$ & $121 \%$ & $118 \%$ & $113 \%$ & $114 \%$ & $114 \%$ & $115 \%$ & $103 \%$ & $116 \%$ & $105 \%$ & $94 \%$ & \\
\hline ZMB & $99 \%$ & $103 \%$ & $103 \%$ & $103 \%$ & $102 \%$ & $122 \%$ & $101 \%$ & $102 \%$ & $100 \%$ & $100 \%$ & $100 \%$ & $96 \%$ & & \\
\hline
\end{tabular}

Source: Exporter-level data collected for the Exporter Dynamics Database project and COMTRADE data.

Note: NA indicates non-availability of data in COMTRADE for comparison. Cells shaded in gray are the year-country pair of data dropped due to a larger discrepancy with respect to COMTRADE data. 


\section{Appendix A3. Countries and Years Used to Define the Five and Eight Consecutive Year Period Used}

\begin{tabular}{|c|c|c|}
\hline Country & Five-year period & Eight-year period \\
\hline ALB & 2008-2012 & 2005-2012 \\
\hline BGD & 2009-2013 & 2006-2013 \\
\hline BGR & 2002-2006 & \\
\hline BOL & 2008-2012 & \\
\hline BWA & $2009-2013 *$ & $2006-2013 *$ \\
\hline CHL & 2008-2012 & 2005-2012 \\
\hline CMR & 2002-2006 & \\
\hline $\mathrm{COL}$ & 2009-2013 & \\
\hline CRI & 2008-2012 & 2005-2012 \\
\hline DOM & 2009-2013 & 2006-2013 \\
\hline ECU & 2009-2013 & 2006-2013 \\
\hline EGY & $2008-2012^{*}$ & \\
\hline GEO & 2008-2012 & $2005-2012$ \\
\hline GTM & 2009-2013 & 2006-2013 \\
\hline HRV & $2008-2012 *$ & \\
\hline IRN & $2006-2010$ & \\
\hline JOR & 2008-2012 & \\
\hline KGZ & 2008-2012 & \\
\hline LBN & $2008-2012 *$ & \\
\hline MAR & 2009-2013 & 2006-2013 \\
\hline MDG & $2007-2011^{*}$ & \\
\hline MEX & 2003-2007 & 2000-2007 \\
\hline PAK & 2006-2010 & 2003-2010 \\
\hline PER & 2009-2013 & 2006-2013 \\
\hline PRY & $2008-2012 *$ & \\
\hline ROU & 2007-2011 & \\
\hline SEN & $2008-2012 *$ & \\
\hline SLV & 2005-2009 & 2002-2009 \\
\hline TZA & 2008-2012 & $2005-2012$ \\
\hline URY & 2008-2012 & $2005-2012$ \\
\hline ZAF & $2008-2012 *$ & 2005-2012 \\
\hline $\mathrm{ZMB}$ & 2007-2011 & 2004-2011 \\
\hline No. countries & 32 & 18 \\
\hline No. countries for gwth acc. & 24 & 17 \\
\hline
\end{tabular}

Source: Exporter-level data collected for the Exporter Dynamics Database project.

Note: "Countries with negative or zero growth over the period indicated. 


\section{References}

Ahn, J., A. Khandelwal, and S.-J. Wei. 2011. “The Role of Intermediates in Facilitating Trade.” Journal of International Economics 84 (1): 73-85.

Arkolakis, C. 2016. “A Unified Theory of Firm Selection and Growth.” Quarterly Journal of Economics 131 (1): 89-155.

Bernard, A., J. B. Jensen, and P. Schott. 2009. "Importers, Exporters and Multinationals: A Portrait of Firms in the U.S. that Trade Goods." In Producer Dynamics: New Evidence from Micro Data, edited by T. Dunne, J. Jensen and M. Roberts. Chicago: University of Chicago Press, p. 513-552.

Bernard, A., S. Redding, and P. Schott. 2010. "Multiple-Product Firms and Product Switching." American Economic Review 100 (1): 70-97.

Bernard, A., J. B. Jensen, S. Redding, and P. Schott. 2010. "Wholesalers and Retailers in US Trade.” American Economic Review 100 (2): 408-13.

Davis, S. J., J. Haltiwanger, and S. Schuh. 1996. Job Creation and Destruction. Cambridge, MA: MIT Press.

Di Giovanni, J., and A. Levchenko. 2012. "Country Size, International Trade and Aggregate Fluctuations in Granular Economies.” Journal of Political Economy 120 (6): 1082-1132.

Di Giovanni, J., A. Levchenko, and I. Mejean. 2014. “Firms, Destinations, and Aggregate Fluctuations.” Econometrica 82 (4): $1303-40$.

Eaton, J., S. Kortum, and F. Kramarz. 2011. “An Anatomy of International Trade: Evidence From French Firms.” Econometrica 79 (5): 1453-98.

Fernandes, A. M., C. Freund, and M. D. Pierola. 2016. "Exporter Behavior, Country Size and Stage of Development: Evidence from the Exporter Dynamics Database.” Journal of Development Economics 119 (C): 121-37.

Freund, C., and M. D. Pierola. 2012. “Export Superstars.” Policy Research Working Paper No. 6222, World Bank, Washington, DC.

- 2015. "Export Superstars." Review of Economics and Statistics 97 (5): 1023-32.

Freund, C., and T. Moran. 2017. "Multinational Investors as Export Superstars: How Emerging-Market Governments Can Reshape Comparative Advantage.” Working Paper No. 17-1, Peterson Institute for International Economics, Washington, DC.

Gabaix, X. 2011. “The Granular Origins of Aggregate Fluctuations.” Econometrica 79 (3): 733-72.

Gaubert, C., and O. Itskhoki. 2016. “Granular Comparative Advantage.” Mimeo. Princeton University, Princeton, NJ.

Helpman, E., M. J. Melitz, and S. R. Yeaple. 2004. "Export Versus FDI with Heterogeneous Firms.” American Economic Review 94 (1): 300-16.

Hsieh, C.-T., and P. J. Klenow. 2009. "Misallocation and Manufacturing TFP in China and India." Quarterly Journal of Economics 124 (4): 1403-48.

Mayer, T., and G. Ottaviano. 2008. “The Happy Few: The Internationalisation of European Firms.” Intereconomics: Review of European Economic Policy 43: 135-48. 